\title{
External Ear Actinic Keratosis
}

National Cancer Institute

\section{Source}

National Cancer Institute. External Ear Actinic Keratosis. NCI Thesaurus. Code C6080.

Actinic keratosis that develops in the skin of the external ear. 